\title{
TRANSFORMASI BUDAYA ASWAJA DI PESANTREN
}

\author{
Aminatuz Zahroh \\ Institut Agama Islam Syarifuddin Lumajang, Indonesia \\ E-mail: aminatuzzahrosyarif@gmail.com
}

\begin{abstract}
Abstrak: Pesantren merupakan salah satu potret institusi penting bagi banyak masyarakat Indonesia. Pesantren merupakan lembaga pendidikan kedua setelah keluarga, yang sangat strategis dalam membentuk budaya yang menghidupi dan membiasakan nilai-nilai positif tertentu, sehingga santri dapat bertumbuh dan berkembang secara alami dengan menginternalisasi nilai-nilai positif tersebut. Di antara nilai-nilai positif tersebut adalah nilainilai ablus sunnab wal jamäah (Aswaja). Transformasi budaya pesantren berbasis Aswaja perlu dilakukan di tengah maraknya isu-isu nasional tentang salafisme, fundamentalisme, radikalisme dan terorisme. Salafisme nampak cenderung kearah fundamentalisme agama dan radikalisme agama, yang berujung pada wacana terorisme dalam Islam. Sayangnya, proses transformasi budaya Aswaja di pesantren banyak mengandalkan pembiasaan dan kurang memperhatikan internalisasi dan institusionalisasi. Sebagai konsekwensinya, pengetahuan dan kompetensi mayoritas santri tentang Aswaja An-Nahdhiyyah, hanya sekedar amaliyah nya saja seperti istighätsah, tablìl dan membaca al-Qur'an surat Yäsìn. Kesimpulan artikel ini menunjukkan bahwa nilai-nilai budaya Aswaja yang diterapkan di pesantren meliputi: nilai tawasut, tawazun, tasamuh dan adl. Pesantren lebih banyak melakukan pembiasaan dari pada internalisasi dan institusionalisasi budaya tersebut.
\end{abstract}

Kata kunci: Transformasi Budaya, Aswaja, Pesantren

\section{Pendahuluan}

Peran pesantren pada masyarakat Indonesia dapat dilihat dari Tridarma pesantren yaitu pendalaman pengetahuan agama Islam (tafaqquh fi ad-din), penyebar luasannya (dakwah) dan pemberdayaan masyarakat. ${ }^{1}$ Di samping itu, pesantren menjadi sebuah media sosialisasi formal, dimana keyakinan-keyakinan, norma-norma dan nilai-nilai Islam ditransmisikan dan ditanamkan melalui pembelajaran. ${ }^{2}$

Pesantren adalah lembaga pendidikan strategis untuk menerapkan empat pilar pendidikan, yang dikemukakan oleh United Nations Educational Scientific and Cultural Organization (UNESCO) yaitu: learning to know (belajar untuk mengetahui), learning to do (belajar untuk melakukan), learning to live together (belajar untuk hidup bersama) dan learning to be (belajar untuk menjadi). ${ }^{3}$

Dalam menghadapi perkembangan zaman, pesantren perlu melakukan tiga hal yaitu: menyesuaikan dengan perkembangan zaman, merespon harapan masyarakat dan tetap menjaga

\footnotetext{
1 Direktorat Jenderal Kelembagaan Agama Islam, Pedoman Tatalksana Pengembangan Agri Bisnis di Pondok Pesantren (Jakarta: Depertemen Agama RI, 2003), vii.

${ }^{2}$ Endang Turmudzi, Perselingkuhan Kiai dan Kekusaan (Yogyakarta: LKiS, 2004), 37

${ }^{3}$ Ashif Az Zafi, "Transformasi Budaya Melalui Lembaga Pendidikan (Pembudayaan dalam Pembentukan Karakter)", Jurnal LP3M - Universitas Sarjanawiyata Tamansiswa Yogyakarta, Vol. 3, No. 2 (Agustus 2017).
} 
kekhasan sebagai lembaga pendidikan Islam. ${ }^{4}$ Karena itulah transformasi budaya pesantren perlu direncanakan dengan baik, agar pesantren dapat dijalankan dengan efektif dan efisien dan dapat merespon laju perkembangan budaya di luar pesantren. Transformasi pesantren dapat didasarkan pada prinsip "continuity and change".

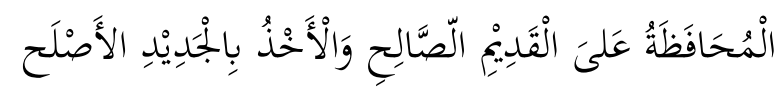

Artinya: Memelihara hal lama yang baik dan mengambil hal baru yang lebih baik.

Hal ini menunjukkan bahwa pesantren terus melakukan perubahan, inovasi dan transformasi, dengan tetap mempertahankan bangunan (konstruksi) lama yang baik dan bermanfaat. $^{5}$

\section{Nilai Budaya dan Pola Pikir Aswaja di Pesantren}

Kaum nabdliyyin menjunjung tinggi nilai-nilai ablussunnah wal jamä’ah sebagai berikut:

1. Al-tawãăun (seimbang) dalam segala hal, termasuk dalam penggunaan dalil 'aqli dan dalil naqli, antara yang bersifat ruh (rühiyah) dan materi (maddiyah), antara keduniaan dan agama, antara urusan pribadi (fardiyyah) dan urusan bersama (jama'iyyah). ${ }^{6}$

2. Al-Tawassuth (sikap tengah-tengah, sedang-sedang, tidak ekstrim kanan dan kiri)

Tawassuth dalam akidah adalah sikap tengah-tengah dalam memahami sifat-sifat Allah antara meniadakan sifat-sifat Allah dan menyamakan sifat Allah dengan sifat makhluq, sedang-sedang dalam memahami perbuatan Allah antara Qadariyah dan Jabariyah. Ia juga sedang-sedang dalam memahami janji Allah antara Murjiah dan Qadariyah dan dalam urusan iman dan agama antara Murjiah dan Jahmiyah. Ia juga sedang-sedang dalam memahami sahabat Rasul antara Rawafid dan Khawarij.

Sedang-sedang dalam aqidah juga dapat dipahami antara pemikiran yang terlalu kendor (ifräth) dan berlebihan (tafrith). Sedangkan di dalam urusan kenabian tidak mengangkat nabi sampai pada tingkat Tuhan. ${ }^{8}$ Pada pokoknya, tawassuth ini mencakup bidang akidah, ibadah, syari'ah, akhlaq dan syi'ar Islam. ${ }^{9}$

\footnotetext{
${ }^{4}$ Abd Halim Soebahar, Kebijakan Pendidikan Islam dari Ordonansi Guru sampai UU Sisdiknas (Jakarta: Raja Grafindo Persada, 2013), 42.

5 Soebahar, Kebijakan, 182.

${ }^{6}$ Yusuf al Qardawy, al Khashaish al 'Ammah li al Islam (Kairo: Muassasah ar Risalah, 1977), 140-147

7 Abdullah bin Muhsin at Turky, Majmal I'tiqad Aimmah As Salaf (Beirut: Asy Syarikah al Muttahidah li at Tawzi', 1992), 8

${ }^{8}$ Yusuf al Qardhawy, Al-Iman Wa Al- Hayah (Bairut: Muassasah Ar-risalah, 1998), 40-44.

${ }^{9}$ Yusuf al Qardawy, al Khashaish al 'Ammah lil al Islam (Kairo: Muassahar Risalah, 1997), 135- 145

70 | Tarbiyatuna: Jurnal Pendidikan Islam; Volume 14, Nomor 1, Februari 2021 p-ISSN: 2085-6539; e-ISSN: 2242-4579; 69-86
} 
3. Al-I'tidãl (adil, tegak lurus dan membela kebenaran)

Adil adalah tidak memihak yang disertai cinta atau kebencian, tidak terpengaruh pada hubungan kerabat, kemaslahatan diri, keluarga dan kelompok tertentu atau keinginan sesaat. ${ }^{10}$ Adil dapat diartikan juga sebagai persamaan dalam memberikan balasan.jika perbuatan baik, maka dibalas dengan baik. Jika perbuatan jelek, maka dibalas dengan jelek. ${ }^{11}$

Menurut Muhammad Abdul Qadir Abu Faris, adil adalah dapat menjaga dari perkara yang haram, jauh dari keragu-raguan dan dapat dipercaya dalam keadaan ridha dan marah. ${ }^{12}$ Kita diperintahkan berbuat adil sekalipun pada musuh kita, karena adil itu akan membuat kita lebih dekat pada taqwa sebagaimana dalam Al-Qur'an surat al Maidah ayat $8 .^{13}$

4. Tasämub (toleransi).

Toleransi adalah menghargai perbedaan dan menghormati prinsip hidup orang lain. Namun bukan berarti mengakui atau membenarkan keyakinan orang lain yang salah dan meneguhkan apa yang diyakini. ${ }^{14}$ Tasämuh juga mencakup anti kekerasan, cinta perdamaian, memberikan kebebasan pada orang lain untuk berfikir kritis, bersikap dan bertindak.

Menurut Michael Walzer, hakekat toleransi mencakup 5 hal berikut:

a. Menerima perbedaan untuk hidup damai

b. Menjadikan keseragaman menuju perbedaan

c. Menerima orang lain punya hak untuk dihargai (moral stoisme)

d. Transparansi pada yang lain, ingin tahu dan menghargai

e. Memberikan dukungan terhadap perbedaan atau mempertegas aspek otonomi. ${ }^{15}$

5. Amar ma'rüf nabi munkar (selalu memiliki kepekaan untuk mendorong perbuatan yang baik dan menolak segala perbuatan yang merendahkan nilai-nilai kehidupan). ${ }^{16}$

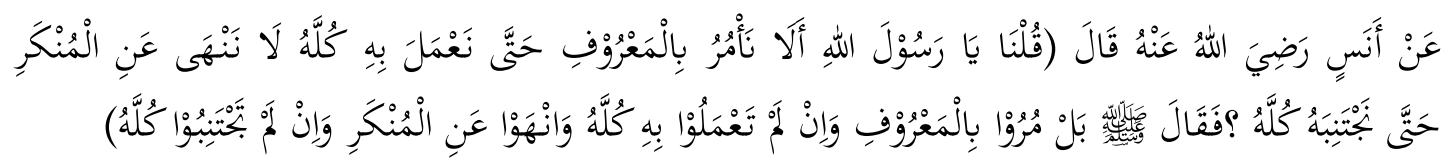

Artinya: Dari Anas RA, kami berkata "ya Rasulallah, bukankah kami tidak menyuruh perkara ma'rüf hingga kami melakukan semuanya dan tidak melarang perkara munkar bingga kami menjaubi semuanya", maka nabi menjawab "tapi perintahlah perkara ma'rüf meskipun kamu tidak melakukan semuanya dan cegablah perkara munkar meskipun kamu tidak menjaubi semuanya."

\footnotetext{
${ }^{10}$ Sayyid Qutub, Fi Drilal al Qur'an,jilid 2 (Beirut: Dar asy Syuruq, 1972), 852

${ }^{11}$ Zahir bin 'Iwad al Alma'I, Dirasat fi at Tafsir al Maudlu'I li al Qur'an al Karim (Riyadh: al Farardaq at Tijariyah, 1983), 325

12 Muhammad Abdul Qadir Abu Faris, al Qadha' fi al Islam (Oman: al-Aqsha, 1978), 37.

${ }^{13}$ Hasan Ahmad Abidin, Huquq al Insan wa wajibatibi fi al Qur'an (Makkah: ats Tsaqafah: 1984), 239.

${ }^{14}$ Muhyiddin Abdusshomad, Hujjah NU Akidah Amaliyah Tradisi (Surabaya: Khalista, 2008), 7-9.

${ }^{15}$ Mohammad Yamin, Vivi Aulia, Meretas Pendidikan Toleransi (Malang: Madani, 2011), 6-7

${ }^{16}$ Forum kajian ke-NU-an, Khittah dan Khidmah (Pati: Raudlah at-tahiriyah, 2014), 44-45
} 
Adapun nilai-nilai tasawuf yang diajarkan di pesantren adalah ikhlas, zuhud, menahan hawa nafsu, istiqāmah dalam beribadah dan tarkiyatun nafsi. ${ }^{17}$

\section{Realitas Transformasi Budaya Aswaja di Pesantren}

Dalam melihat realitas transformasi budaya Aswaja di pesantren perlu digunakan dua tataran institusional dan tataran ideal. Pada tataran institusional akar-akar transformasi di pesantren sudah ada, sekalipun itu sangat sederhana dan perlu dikembangkan. Sedangkan dari tataran ideal (visi), kita agak mengalami kesulitan, sebab sebuah visi pesantren menuntut adanya kemampuan pesantren menyerap khazanah dari luar sehingga muncul sinergi antara khazanah pesantren dengan khazanah luar pesantren.

Budaya pesantren merupakan suatu kekuatan yang tidak tampak, yang dapat menggerakkan orang-orang dalam pesantren untuk melakukan aktifitas kerja. Budaya pesantren yang kuat sebagaimana budaya organisasi, pada umumnya dapat mendukung tercapainya tujuantujuan pesantren, sebaliknya budaya pesantren yang lemah akan dapat menghambat tercapainya tujuan-tujuan pesantren. ${ }^{18}$ Budaya pesantren dapat membuat orang-orang didalamnya dengan mudah dapat memahami prosedur kerja dan hubungan yang didefinisikan dengan jelas. ${ }^{19}$

Transformasi budaya pesantren perlu direncanakan dengan baik, karena pesantren merupakan lembaga pendidikan kedua setelah keluarga yang sangat strategis dalam membentuk budaya yang menghidupi dan membiasakan nilai-nilai positif tertentu, sehingga santri dapat berkembang secara alami dengan menginternalisasi nilai-nilai positif tersebut. ${ }^{20} \mathrm{Di}$ antara nilainilai positif tersebut adalah nilai Aswaja

Transformasi budaya Aswaja sangat tepat dilakukan di pesantren karena pesantren merupakan satu-satunya lembaga pendidikan dan dakwah Islam yang strategis untuk mendalami agama Islam secara terarah.

Pembelajaran di pondok pesantren yang bersumber dari kitab salaf merupakan proses pelestarian dan pengamalan ajaran Islamberbasis nilai Aswaja. ${ }^{21}$ Aswaja bukan hanya ideologi yang menjadi orientasi dan ruh dari gerak perkembangan pesantren, juga bukan hanya menjadi landasan berfikir personil di dalamnya, tetapi juga menjadi identitas pesantren yang dapatmembedakannya dengan pesantren lain. ${ }^{22}$

17 Tim Penulis Batartama, Trilogi Ablus Sunnah, Akidah, Syariah dan Tasawuf (Pasuruan: Pustaka Sidogiri, 2015), 276278.

${ }^{18}$ Edy Sutriono, Budaya Organsasi (Jakarta: Kencana, 2010),3

${ }^{19}$ Gary Yukl, Kepemimpinan dalam Organisasi (ed. 5), terj Budi Supriyanto (New Jersey: Prentice - Hall Inc, 2005), 417

${ }^{20}$ Fidelis E. Waruwn, Membangun Budaya Berbasis Nilai (Yogyakarta: Kanisius, 2010), 55.

${ }^{21}$ Asep Syaifuddin Halim, Membumikan Aswaja Pegangan Para Guru NU (Surabaya: Khalista, 2015), 1-2.

22 Departemen Republik Indonesia Direktorat Jenderal Pendidikan Islam, Direktorat Pendidikan Islam, PostTradisionalisme Islam (Jakarta: DEPAK, 2007), 46 
Diantara nilai aswaja tersebut adalah nilai tawä̌un (keseimbangan) dan nilai 'adalāh (keadilan). Pesantren menjunjung tinggi kedua nilai tersebut, sampai pada penerapan kesetaraan gender. Penerapan nilai ini dapat dibauktikan dengan adanya pemberian hak terhadap perempuan secara imbang dan adil (sesuai dengan peran yang dapat diambilnya) bukan menyamakan hak perempuan dan laki-laki.

Dalam kondisi obyektifnya, banyak konstruksi budaya aswaja di pesantren hanya berupa simbol-simbol, keteladanan, gerak tubuh dan kegiatan-kegiatan keaswajaan, belum sampai pada produk-produk materi, folkway, software of mind atau ideologi dan cerita-cerita yang dihidupkan. Sedangkan proses transformasinya banyak mengandalkan pembiasaan dan kurang memperhatikan proses transformasi melalui internalisasi dan institusionalisasi.Sebagai konsekwensinya, pengetahuan dan kompetensi mayoritas santri tentang budaya pesantren berbasis aswaja lebih banyak bersifat amaliyah seperti istighätsah,tahlil, membaca al Qur'an surat yāsin dan lain sebagainya.

Sejatinya, budaya aswaja di pesantren perlu juga dilakukan melalui produk-produk materi, folkway, software of mind, cerita-cerita yang dihidupkan, pola interaksi aswajais, bahasa, penanaman nilai demokratis, mencetak kader ulama aswaja dengan diselenggarakannya lembaga khusus untuk mendalami Aswaja.

\section{Respon Internal dan Eksternal Pesantren Terhadap Transformasi Budaya Aswaja}

Adapun respon internal pesantren terhadap transformasi budaya berbasis aswaja dapat dijelaskan sebagai berikut:

1. Semakin banyaknya santri yang berminat mengikuti kegiatan Aswaja

2. Diselenggarakannya asrama santri yang khusus mengkaji kitab kuning yang sarat dengan nilai-nilai aswaja.

3. Tersedianya buku-buku dan kitab-kitab terkait dengan aswaja di perpustakaan pesantren, baik yang manual maupun digital.

4. Semakin banyaknya santri yang melanjutkan study pada perguruan tinggi, untuk memperdalam pemahamannya tentang Islam khususnya Aswaja.

Adapun respon eksternal pesantren terhadap transformasi budaya pesantren dapat dilihat sebagai berikut:

1. Semakin meningkatnya kepercayaan masyarakat yang salah satunya dapat dilihat dari semakin meningkatnya jumlah santri.

2. Diterimanya alumni pesantren di masyarakat sebagai anggota masyarakat, tokoh masyarakat dan pengasuh pesantren yang berbasis aswaja.

3. Kemudahan perizinan penyelenggaraan kegiatan pelatihan-pelatihan aswaja oleh pemerintah. 


\section{Proses Transformasi Budaya Aswaja di Pesantren}

1. Pembiasaan Nilai Ablus Sunnab wal Jamäah

Proses transformasi budaya Aswaja di pesantren pada umumnya diawali dengan pembiasaan nilai Aswaja. Adapun proses tersebut Abdullah Nasih Ulwan adalah sebagai berikut: ${ }^{23}$

a. Talqin (menuntun).

Talqin ini dimaksudkan agar anak dapat mempraktekkan budaya Aswaja dengan baik dan benar.

b. Ta'wid (pembiasaan)

Pembiasaan ini dimaksudkan agar anak terbiasa mengamalkan dan mempraktekkan budaya Aswaja. Pembiasaan nilai Aswaja dapat dimulai dengan rancangan kurikulum pesantren yang mengarah pada penguatan nilai-nilai Aswaja. Adapun proporsi kegiatan yang ideal berdasarkan rancangan kurikulum tersebut yaitu bersifat aqliyyah 50\%, yang bersifat qalbiyyah 40\% dan bersifat jasadiyyah 10\%. Proporsi ini dianggap imbang (Tawãzun) dengan menempatkan kegiatan aqliyyah pada proporsi terbesar. ${ }^{24}$ Nilai tawāzun yang ditanamkan kepada santri juga dalam rangka melaksanakan nilai 'itidal (keadilan). Hal ini sesuai dengan QS. Al-Hadiid: 25

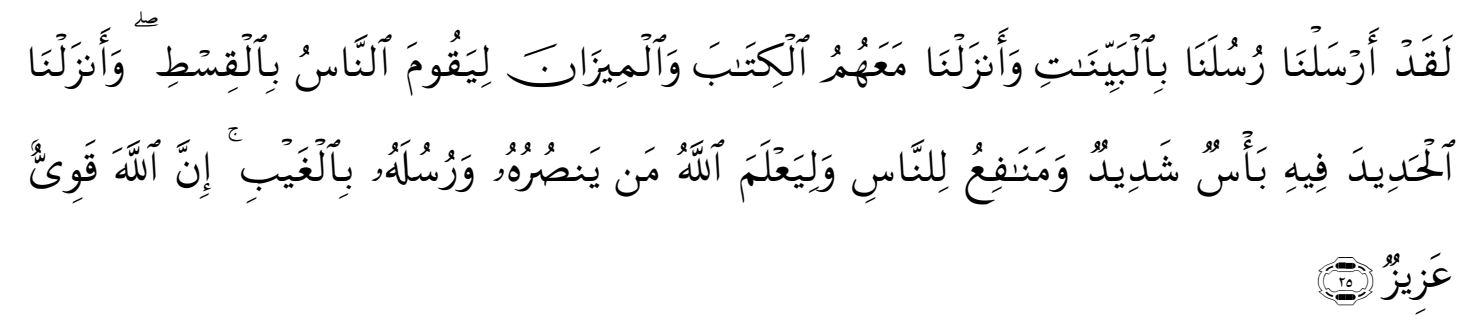

Artinya: Sesunggubnya Kami telah mengutus Rasul-rasul Kami dengan membawa bukti-bukti yang nyata dan telah Kami turunkan bersama mereka Al kitab dan neraca (keadilan) supaya manusia dapat melaksanakan keadilan. dan Kami ciptakan besi yang padanya terdapat kekuatan yang hebat dan berbagai manfaat bagi manusia, (supaya mereka mempergunakan besi itu) dan supaya Allah mengetahui siapa yang menolong (agama) Nya dan rasul-rasul-Nya Padabal Allah tidak dilihatnya. Sesunggubnya Allah Maba kuat lagi Maha Perkasa.

Hal ini disebabkan karena menurut Parson, tindakan seseorang sangat dipengaruhi oleh informasi yang diterima. Informasi ini bisa berbentuk pengetahuan yang dibaca, didengarkan dan dipelajari. Informasi ini kemudian membentuk keyakinan terhadap informasi yang diterima. Di sinilah terbentuk paradigma hidup seseorang. Selanjutnya dari paradigma ini akan muncul sikap setuju atau tidak setuju terhadap apa yang sudah dipelajari dan yang sedang dipelajari. Dari apa yang disetujui akan muncul niat untuk 
melakukannya. Sedangkan dari apa yang tidak disetujui akan muncul niat untuk meninggalkannya. Dari niat inilah muncul tindakan nyata.

Gambar 1.1 Teori tindakan Parson

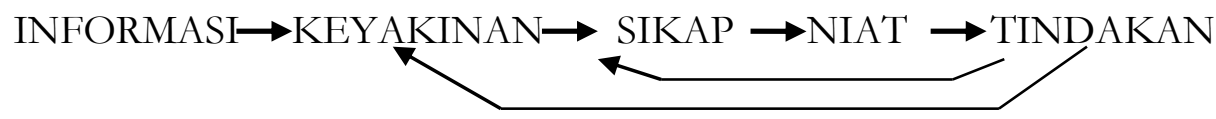

Feedback

Yang tidak kalah pentingnya dari muatan kurikulum tersebut adalah bidden curriculum. Hidden curriculum adalah semua yang diajarkan dan dipelajari secara tidak resmi melalui proses pembelajaran. Ketika siswa berada dalam situasi yang berbeda mereka secara efektif diajarkan nilai yang berbeda tergantung pada dimana dia berada. Hidden Curriculum dapat dibentuk melalui budaya, bahasa dan labelling. ${ }^{25}$

Pembiasaan nilai Aswaja dapat berjalan dengan efektif jika komunikasi didasarkan pada pendekatan antara kyai dengan santri, kiai dengan pengurus, pengurus dan santri serta santri dan santri. Cara membangun kedekatan;

1) Berbagi hal-hal yang sifatnya informasi

2) Berbagi opini atau pendapat

3) Berbagi perasaan ${ }^{26}$

Pembiasaan nilai Aswaja lebih mudah dilakukan di pesantren karena beberapa faktor berikut:

1) Dalam niat melakukan suatu kebaikan, selalu ditanamkan keikhlasan karena Allah.

2) Dalam melakukan suatu kebaikan, ditanamkan motivasi untuk menegakkan kalimat Allah (li i'lai kalimatillah) dan berjuang di jalan Allah (jihad fi sabilillah)

3) Dalam kehidupan bermasyarakat, baik dalam scope yang kecil (seperti pesantren) maupun scope yang besar (masyarakat yang sebenarnya) selalu ditanamkan semangat Ukhuwwah ISLAMLAH, silatur rahim dan amar ma'rüf nabi munkar.

4) Semangat amar ma'rüf nabi munkar ini dilandaskan pada hadis nabi: Dari Anas, kami berkata 'Ya Rasulallah, bukankah kami tidak menyuruh perkara ma'rūf hingga kami melakukan semuanya dan tidak melarang hingga kami menjauhinya semuanya?”. Kemudian Rasulullah menjawab: “Tapi perintahlah perkara ma'rūf meskipun kamu tidak melakukan semuanya dan cegahlah perkara munkar meskipun kamu tidak menjauhi semuanya."

${ }_{25}$ Barlette, Steve, dan Diana Burton, Introduction to Education Studies, Edisi, 2 (Los Angles: SAGE Publication, 2007), 149-154.

${ }^{26}$ David Pranata, Communication Made Easy (Jakarta: Media Komputindo, 2016), 56-58 
Mudahnya pembiasaan nilai Aswaja di pesantren tersebut, karena beberapa kondisi khas yang dimiliki pesantren,yaitu sebagai berikut:

1) Kebersamaan kyai dan santri

2) Kesederhanaan

3) Kesetaraan untuk semua santri

4) Kemudahan dalam riyadhah dan mujahadah

5) Keterpaduan antara sekolah formal dan madrasah Diniyah

6) Keterdapuan antara teori dan praktek, ta’lim dan tarbiyah.

7) Keterpaduan sistem madrasah dari tingkat paling rendah sampai tingkat tertinggi yang di selenggarakan oleh pesantren tersebut.

Pembiasaan nilai Ablus Sunnah wal Jamäabbisa dilakukan dengan hal-hal berikut:

1) Nilai Tawassut (Moderat atau Tengah-tengah).

Pembiasaan nilai ini dapat dilakukan dengan penentuan seragam madrasah yang sederhana, anjuran untuk puasa sunnah di hari-hari sunnah berpuasa dengan membuka kantin pada malam hari untuk melayani santri yang berpuasa,lokalisasi warung tetangga sekitar dengan menyediakan menu makanan yang sederhana, kerja sama dengan Dinkes dan ikatan Bidan untuk survey makanan.

Hal ini juga dapat dilakukan denagan pennetuan harga maksimal penjualan pakaian, pemberlakukan ketentuan bahwa santri tidak boleh membawa pakaian melebihi 5 setel pakaian selain pakaian seragam, pemantauan buku bacaan santri, penerapan kerangka berfikir moderat, anjuran pada orang tua untuk tidak mengirim uang berlebihan dan ditentukan batas maksimalnya serta pelaksanaan hasil rapat yang menjunjung tinggi tawassuth.

2) Nilai Tawã̃un (Seimbang)

Pembiasaan nilai ini dapat dilakukan dengan kesamaan penyusunan kurikulum, kegiatan-kegiatan yang dilaksanakan dan kitab-kitab yang diajarkan antara pondok putera dan puteri.Kurikulum disusun secara berimbang antara putera dan puteri.Kegiatanpun berimbang secara proporsional antara kegiatan yang bersifat aqliyyah, qalbiyyah dan jasadiyyah, antara pelajaran agama dan umum.Pelajaran agama lebih banyak proporsinya daripada pelajaran umum.Hal ini untuk menunjukkan cirri khas kepesantrenan.

3) Nilai Tasamub(Toleransi)

Pembiasaan nilai tasamuh dapat dilakukan dengan menyikapi santri yang memiliki aliran lain dengan tidak mengkafirkannya, menghargai perbedaan pendapat, sikap dan 
tingkah laku orang lain. Pelaksanaan babtsul masa'il oleh masing-masing madrasah untuk memberikan kebebasan berpendapat kepada santri menjadi hal yang penting. Demikian pula dengan pemberlakuan tata tertib yang mendukung toleransi antar santri yang heterogen.

Dalam prakteknya penerapan nilai tasamub di pesantren ini erat kaitannya dengan penerapan nilai ats tsabat wa al murunah (teguh tapi fleksibel) dengan mempertimbangkan nilai waqi'iyyah (realistis). Nilai tasamub di pesantren juga diterapkan dengan memberikan kesempatan bagi orang lain untuk berbuat kebaikan dan dispensasi dalam pemenuhan terhadap iuaran pendidikan pesanten bagi dua atau tiga bersaudara.

4) Nilai I'tidãl (Tegak Lurus dan Tidak Memihak)

Pembiasaan nilai i'tidãl nampak dalampenempatan santri pada asrama dengan tidak memandang tingkat sosial budayanya, pemberian kesempatan pada santri mempelajari kepemimpinan dan manajemen praktis.pemberian dispensasi pada santri yang berhak menerimanya.Suksesi kepemimpinan yang diterapkan di pesantren ini memberikan kesempatan pada siapapun untuk menduduki jabatan tertentu selama memungkinkan, dibutuhkan pesantren dan memenuhi syarat.

Hal ini dapat juga nampak pada sistem pengangkatan ustadz dan karyawan dan pemberlakuan tata tertib yang sama diantara santri dengan tetap mempertimbangkan pengecualian (mustatsnayat) dan dispensasi (rukhshah).

5) Nilai amar márüf nabi munkar (Menyuruh Kebaikan Melarang Kemunkaran)

Nilai ini juga penting dibiasakan pada santri meskipun nilai tersebuthukumnya fardu kifayah bukan fardu ain. Karena amar ma'rüf nabi munkar sangat diperlukan di masyarakat. Hal tersebut berdasarkan al Qur'an surat ali Imran ayat 104:

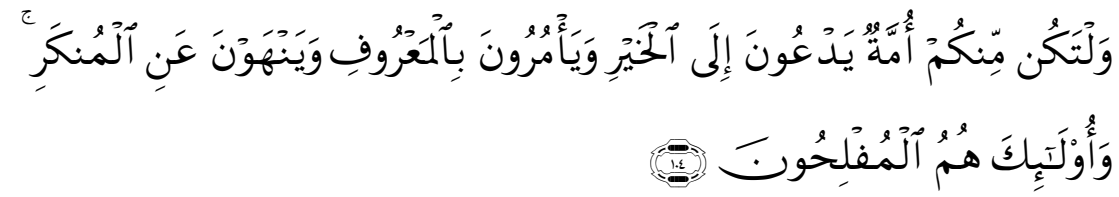

Artinya: dan hendaklah ada di antara kamu segolongan umat yang menyeru kepada kebajikan, menyuruh kepada yang ma'ruf dan mencegah dari yang munkar merekalab orang-orang yang beruntung.

Yang dimaksud ma'rüf dalam ayat tersebut adalah segala perbuatan yang mendekatkan kita kepada Allah; sedangkan Munkar adalah segala perbuatan yang menjauhkan kita dari pada-Nya. 
Dalam ayat tersebut menggunakan lafadz min ba'dhiyyah yang berarti sebagian. Ayat tersebut menjelaskan tentang keutamaan amar ma'rüf nabi munkar yaitu membuat orang beruntung di dunia dan akhirat serta menjadi umat yang terbaik. ${ }^{27}$

Santri dibiasakan melakukan amar ma'rüf nabi munkar dari scope terkecil seperti pada teman akrab, kemudian teman sekamar atau sekelas, satu sekolah, satu pondok sampai pada scope terbesar seperti masyarakat pada umumnya. Diadakannya kepengurusan pesantren dari level paling bawah sampai paling tinggi serta pengiriman guru tugas dan da’i pada masyarakat juga merupakan penerapan nilai amar ma'ruf nabi munkar.

Nilai amar ma'ruf nabi munkar ini juga nampak dalam sikap pengasuh pesantren yang selalu open house terhadap tamu yang datang berkunjung, baik tamu formal maupun tidak formal. Di depan kantor pesantren diumumkan etika berpakaian untuk para tamu, yaitu berpakaian Islami dan sopan dan adanya pemisahan kelas antara putera dan puteri. Adanya peraturan wajib tinggal di pesantren bagi siswa dari luar pesantren yangrumahnya lebih dari $1 \mathrm{~km}$ dari pesantren.

Anjuran agar santri mampu berorganisasi dengan baik sebagai salah satu bentuk amar ma'ruf nabi munkar. Latihan berpidato tiap malam selasa diadakan perkamar untuk melatih santri melakukan nilai amar ma'ruf nabi munkar dengan berani tampil melakukan dakwah bi al lisan. Latihan solawat perkamar dilakukan untuk melatih santri dalam pengembangan bakat dan minat serta melatih santri siap berperan dalam majelis ta'lim di masyarakat kelak. Program desa binaan oleh mahasantri yang sedang menempuh KKN juga merupakan praktek amar ma'ruf nabi munkar di masyarakat.

2. Internalisasi Budaya Ahlus sunnah waal Jamäah

Internalisasi adalah penggabungan atau penyatuan sikap, standar tingkah laku, pendapat dan seterusnya di dalam kepribadian. Reber sebagaiman dikutip Mulyana dan Gunawan mendefinisikan internalisasi sebagai menyatunya nilai dalam diri seseorang ataudalam istilah psikologi merupakan penyesuaian keyakinan, nilai, sikap dan praktek serta aturan-aturan baku pada diri seseorang. ${ }^{28}$

Keyakinan merupakan bagian dari perilaku yang digunakan untuk menjelaskan dan mengarahkan corak-corak perilaku. Semua keyakinan merupakan keluaran dari perilaku, keyakinan menggambarkan makna yang terkandung dalam pengalaman yang kita miliki akibat perilaku kita yang sebelumnya. ${ }^{29}$

\footnotetext{
${ }_{27}$ Muhammad Jamaluddin al Qasimi ad Ddimasyqi, Mau'idzah al Mu'minin (Beirut: Dar al fikr, tt), 177-178

${ }^{28}$ Gunawan, Ali Hasan Siswanto, Islam Nusantara dan Kepesantrenan (Yogyakarta: Interpena, 2016), 177-178

${ }^{29}$ William F. O’Nell, Educational Ideologies Contemporary Expressions of Education Philosophies (California: Good Year Publishing Compani, 1981), 52 
Dalam meramalkan perilaku pendidikan adalah penting mengetahui filosofi (termasuk nilai-nilai dasar) seseorang. Namun mengetahui prioritas khusus atau peringkat nilai-nilai yang ada dalam filosofi orang itu jauh lebih penting lagi. Pada umumnya 4 pertanyaan berikut penting sekali:

a. Apa sajakah nilai-nilai mendasar? (Apa komitmen nilainya secara menyeluruh?)

b. Seberapa dalamkah ia terikat nilai-nilai? Seberapa kuat komitmennya?

c. Secara umum, apa peringkat prioritas nilai-nilai tersebut dan bagaiman kaitaanya satu sama lain? Apa yang paling diperhatikannya dan apa struktur nilai / value gestalt yang dihasilkan dari situ?

d. Bagaimanakah individu yang bersangkutan memahami nilai-nilai itu dalam kaitannya dengan situasi yang dihadapinya? Apa relevansi situasional dengan komitmen personal itu? $?^{30}$

Dari penjelasan tersebut jelaslah bahwa secara tersirat langkah-langkah internalisasi nilai Aswaja di pesantren sama halnya dengan langkah-langkah merubah sikap dan prilaku melalui kegiatan eksperiental (pemberian pengalaman) sebagai berikut:

a. Menciptakan keterbukaan

b. Memajukan pemahaman. ${ }^{31}$

Kedua langkah tersebut seharusnya dilanjutkan dengan empat langkah internalisasi nilai sebagai berikut:

a. Sosialisasi yaitu sharing tentang apa yang kita tahu dengan cara informal

b. Eksternalisasi yaitu refleksi dari hasil yang sudah kita pelajari dan sharing dengan cara forma, sehingga pengetahuan kita menjadi eksplisit.

c. Kombinasi yaitu memadukan pengetahuan eksplisit dengan pendekatan tertentu. Memadukan pengetahuan dengan praktek.

d. Internalisasi yaitu pengetahuan itu dipraktekkan hingga tertanam mendarah daging dan memiliki dampak dalam kehidupan pembelajar. ${ }^{32}$

Adapun secara garis besar dalam internalisasi nilai Aswaja, perlu melakukan tiga hal penting sebagai berikut: ${ }^{33}$

a. Menyambungkan dan mengikat hatinya dengan aqidah Islam Aswaja

b. Menyelamatkan dirinya dari selain aqidah Islam Aswaja

c. Merubah lingkungan dengan melakukan pemahaman terhadap Aswaja.

${ }^{30}$ William F.O’Nell, Educational Ideologies, 72

${ }^{31}$ Carlette Jackson Hordin, Effective Classroom Management (New Jersey: Upper Saddle River, 2004), 21

${ }^{32}$ Sue Crowley, Challenging, 81

33 Abdullah Nasih Ulwan, Tarbiyah al Awlad fi al Islam, Juz 2 (Beirut: Dar as Salam), 672 
Internalisasi nilai budaya Aswaja mutlak diperlukan di pesantren karena dalam kenyataan dan dialektika sejarah pesantren terjadi beberapa hal berikut:

a. Pesantren merupakan tempat pertemuan antara budaya, peradaban dan tradisi yang berbeda-beda di kalangan santri.

b. Dalam pesantren terjadi percampuran, saling mempengaruhi dan benturan budaya santri.

Adapun cara memahami dan memahamkan perbedaan sebagai sebuah keniscayaan:

a. Perbedaan hidup sebagai sebuah pemberian dan rahmat dari Allah

b. Perbedaan harus bisa menciptakan kerukunan hidup yang lebih membawa sebuah perdamaian

c. Perbedaan harus mampu menanamkan nilai-nilai siap berbeda tapi siap menerima perbedaan untuk menjalani kehidupan sosial yang harmonis.

d. Perbedaan pandangan harus bisa semakin melenturkan pola pikir masyarakat dari keras menjadi lembut. ${ }^{34}$

Untuk menyikapi tersebut, pesantren melakukan internalisasi nilai toleransi bukan hanya sesama santri dan sesama muslim, tapi juga toleransi antar ummat beragama. Hal ini lebih mudah dilakukan karena santri lebih menguasai tentang ajaran Islam dan lebih bisa menerapkannya dalam kehidupan bermasyarakat. Nilai toleransi dapat diinternalisasikan dengan saling menghargai dalam beberapa hal berikut:

a. Keyakinan dan peribadatan

b. Hidup berdampingan dengan agama lain

c. Hubungan bermasyarakat

d. Dialog antar ummat beragama. Hal ini didasarkan pada al Qur'an:

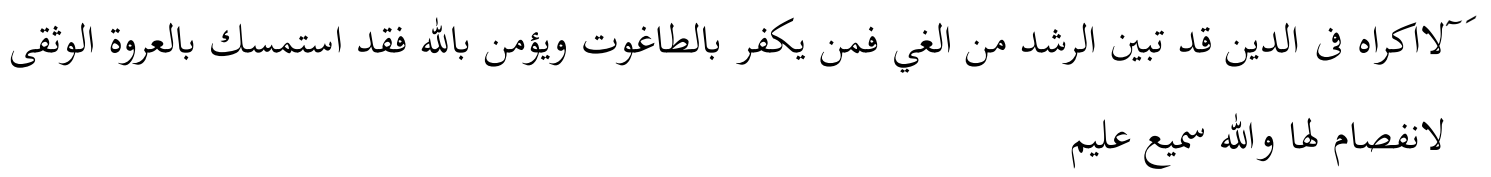

Artinya: Tidak ada paksaan untuk (memasuki) agama (Islam); Sesungguhnya telah jelas jalan yang benar daripada jalan yang sesat. karena itu Barangsiapa yang ingkar kepada Thaghut dan beriman kepada Allah, Maka Sesunggubnya ia telah berpegang kepada bubul tali yang Amat kuat yang tidak akan putus. dan Allab Maha mendengar lagi Maha mengetabui. (QS. Al-Baqarah: 256)

Membincangkan tentang toleransi tidak terlepas dari pembicaraan tentang level keterlibatan. Level keterlibatan terbagi menjadi: minimal, partial dan maksimal. ${ }^{35}$ Di

\footnotetext{
34 Mohammmad Yamin dan Vivi Aulia, Mereta Pendidikan Toleransis (Malang: Madani, 2011), 45-46

${ }^{35}$ Edgah H. Schein, Organizational Culture dan Leadership (San Francisco: Jossey-Bass),181

80 | Tarbiyatuna: Jurnal Pendidikan Islam; Volume 14, Nomor 1, Februari 2021 
pesantren, sikap toleransi lebih mudah ditanamkan pada santri, karena terdapat keterlibatan yang maksimal dari semua personil pesantren dalam kehidupan yang heterogen.

Pembiasaan nilai Aswaja belum cukup kuat tapi perlu dilengkapi dengan internalisasinya. Berikut ini hal-hal yang dilakukan pesantren yang berkaitan dengan internalisasi budaya Aswaja:

a. Babtsul Masa'il mingguan

b. Mendirikan Lembaga Penelitian dan Studi Islam

c. Bahtsul Masa'il untuk para alumni yang dihadiri juga oleh santri-santri terpilih

d. Kurikulum madrasah dan sekolah memuat materi Aswaja

e. Pengarahan, sambutan dan taushiyah pengasuh pada santri yang sarat dengan nilai-nilai aswaja pada acara-acara resmi pondok.

f. Melalui Orientasi Kepesantrenan Berbasis Aswaja untuk santri baru,sehingga santri memahami budaya pesantren berbasis aswaja

g. Melalui Orientasi Calon Alumni, sehingga alumni pesantren terkait dapat mempertahankan dan mengembangkan paham aswajanya di masyarakat

h. Pengajian kitab tentang adab keaswajaan dan cinta rasul.

3. Institusionalisasi budaya Ahlus Sunnah wal Jamā’ah

Dalam melakukan institusionalisasi nilai Aswaja di pesantren terlebih dahulu perlu melakukan perubahan dan pemantapan mindset dikalangan warga pesantren. Mindset adalah hasil pengalaman, keyakinan, nilai-nilai yang telah diinternalisasi dan diyakini oleh seseorang yang mempengaruhi cara-caranya bersikap dan berprilaku. ${ }^{36}$ Setelah mindset Aswaja sudah mantap, maka perlu melakukan kegiatan-kegiatan rutin Aswaja. Adapun langkah-langkah mengajarkan rutinitas adalah sebagai berikut:

a. Tentukan dengan jelas harapan dan tujuan kita

b. Rencanakan bagaimana kita akan mengajarkan harapan kita

c. Jelaskan harapan kita dan alasannya.

d. Berikan contoh harapan santri.

e. Bimbinglah santri melalui praktek menggunakan narasi penguatan

f. Berikan feedback terhadap performance santri dalam praktek

g. Review harapan kita sebanyak waktu yang dibutuhkan dalam melakukan praktek $^{37}$

Ketika anak didik tidak mau berpastisipasi dalam institusionalisasi dengan melakukan rutinitas atau pembiasaan nilai Aswaja maka ulangilah prakteknya, bukan perintahnya,

${ }^{36}$ Fidelis E Waruwu, Membangun Budaya Berbasis Nilai, Panduan Pelatihan bagi Trainer (Yogyakarta: Kanisius), 125-126

${ }^{37}$ Angela Powell, Classroom Management That Makes Teaching More Effective, Efficient and Enjoyble (USA: 2009), 99-102 
kembali dan coba lagi. ${ }^{38}$ Jika hal tersebut tidak berhasil, maka hendaknya memberlakukan tata tertib yang memenuhi beberapa komponen sebagai berikut:

a. Relational rules yaitu komponen tata tertib yang mengatur anak didik dalam melakukan relasi dengan orang lain.

b. Structuring rules yaitu komponen tata tertib yang mengatur anak didik dalam mengikuti kegiatan.

c. Protecting rules yaitu komponen tata tertib yang mengatur anak didik dalam memberikan ketenangan pada teman-temannya

d. Personal rules yaitu komponen tata tertib yang mengatur anak didik dalam merefleksikan diri

e. Etiquette rules yaitu komponen tata tertib yang mengatur anak didik dalam bersikap dalam situasi sosial. $^{39}$

Untuk mempermudah melakukan proses transformasi budaya di pesantren, maka dapat mempertimbangkan teori tindakan menurut Talcott Parson, bahwa beberapa faktor yang mempengaruhi terbentuknya suatu tindakan adalah norma, nilai dan ide yang dapat ditransformasikan melalui pembiasaan dan internalisasi, seerta situasi dan kondisi yang dapat ditransformasikan melalui institusionalisasi.

Proses transformasi budaya Aswaja melalui institusionalisasi nilai Aswaja di pesantren secara garis besar dapat dijelaskan sebagai berikut:

a. Penyusunan kurikulum Aswaja meliputi mata pelajaran, desain pembelajaran dan pengalaman hidup berAswaja, baik dalam pendidikan formal, penddikan diniyah formal dan pendidikan non formal (ma'badiyah)

b. Komunikasi verbal, non verbal, formal dan non formal

c. Kegiatan sehari-hari individu santri seperti makan dan berpakaian.

d. Kegiatan bersama seperti shalat Jamā’ah, dzikir bersama, musyawarah kitab, rapat pengurus, sekolah dan mengaji kitab.

e. Penegakan tata tertib untuk santri, pengurus dan ustadz.

f. Pengembangan nilai Aswaja, sikap dan tingkah laku Aswajais

g. Pengenalan simbul-simbul Aswaja melalui slogan, gambar, identitas kultural yang meliputi penampilan, pola interaksi dan istilah-istilah khusus yang digunakan

h. Keteladanan dari kyai, ustadz, dan pengurus

i. Cerita-cerita kepesantrenan yang turun-temurun dari generasi ke generasi

j. Kegiatan rutin keAswajaan baik harian, mingguan, bulanan atau tahunan

38 Angela Powell, Classroom, 104-105

${ }^{39}$ Carlette Jackson Hardin, Effective Classroom Management, ed.3 (England: Pearson, 2014), 195

82 | Tarbiyatuna: Jurnal Pendidikan Islam; Volume 14, Nomor 1, Februari 2021 p-ISSN: 2085-6539; e-ISSN: 2242-4579; 69-86 
Sebagai langkah institusionalisasi nilai Aswaja, pesantren dapat mendirikan Aswaja Center atau melaksanakan gerakan Aswaja yang anggotanya adalah santri-santri dewasa yang ingin mendalami Aswaja dan akan melakukan Aswajanisasi di masyarakat. Tutornya adalah para alumni yang ahli dalam bidang Aswaja.

Berkaitan dengan institusionalisasi budaya Aswaja,pesantren dapat melakukan pembekalan pada Orientasi Santri Baru yang menyampaikan dasar-dasar Aswaja dan pembekalan untuk calon Alumni untuk memantapkan internalisasi Aswaja sebagai bekal ketika menghadapi masyarakat yang memiliki keyakinan yang berbeda-beda. Disamping itu rekrutmen ustadz dan karyawan tidak hanya dengan tes wawancara seputar tujuan melamar kerja dan penguasaan tentang materi yang akan diampu, tapi juga tes tentang wawasan keAswajaan dan praktek keAswajaan seperti tahlil, istighatsah dan lain-lain

Sedangkan pesantren yang memiliki perguruan tinggi dapat memanfaatkan perguruan tinggi tersebut sebagai wadah bagi para mahasantri yang sudah dewasa untuk lebih mendalami Aswaja. Manfaat lain yang didapatkan dari hal ini adalah moral tetap terjaga, tafaqquh fi addin di kalangan mahasiswa tetap berlanjut, memperahankan tradisi pesantren dan kerangka berfikir Aswaja lebih mudah diterima dan diterapkan, karena dapat didukung oleh wawasan akademik.

Institusionalisasi ini dapat mempermudah proses transformasi budaya Aswaja karena para pembelajar dewasa memiliki karakteristik sebagai berikut:

a. Memiliki motivasi belajar yang tinggi

b. Ingin mengetahui isi perkuliahan yang menguntungkan mereka.

c. Bagi orang dewasa, waktu menjadi pertimbangan yang penting

d. Para dewasa menghargai dan menghormati instruktur

e. Para dewasa membawa pengalaman di luar kelas tentang personal dan kehidupan kerja ke dalam kelas

f. Para dewasa yang matang dapat membimbing dirinya dan mandiri.

g. Para dewasa ingin berpartisipasi dalam pengambilan keputusan

h. Para dewasa mungkin kurang fleksibel dari pada yang lebih muda karena terbebani oleh rutinitas

i. Beberapa dewasa lebih suka kerjasama dalam kelompok dan bersosialisasi. ${ }^{40}$

Internalisasi dan institusionalisasi nilai Aswaja akan berjalan efektifdengan melakukan rasionalisasi nilai Aswaja. Rasionalisasi nilai Aswajaadalah bentuk pemikiran rasional dan

${ }^{40}$ Gary R. Morrison, Designing Effective Instruction (Hoboken: River Street, 2011), 63 
ilmiah tentang transformasi nilai Aswaja.Hal ini dilakukan dengan rasionalisasi terhadap manajemen pesantren dan rasionalisasi terhadap situasi sosial umat Islam secara umum.

Oleh karena transformasi budaya Aswaja itu diharapkan bukan hanya berdampak baik pada santri, tapi juga berdampak baik pada masyarakat, maka proses pembelajarannya lebih baik menggunakan pembelajaran kontekstual.

Adapun 3 tipe konteks pembelajaran adalah sebagai berikut:

a. Konteks yang berorientasi (the orienting context). Dalam hal ini transformasi budaya Aswaja diselaraskan dengan orientasi pesantren.

b. Konteks pembelajaran (the instructional context). Dalam hal ini transformasi budaya pesantren diselaraskan dengan pembelajaran pada pesantren pada umumnya.

c. Konteks pemindahan (the transfer context) yang mempertimbangkan kesempatan untuk mentransfer pengetahuan dan keahlian dalam Aswaja pada situasi baru. ${ }^{41}$

Transformasi budaya Aswaja di pesantrendapat didasarkan pada tiga prinsip utama pembelajaran kontekstual menurut Elaine B. Jhonson yaitu:

a. Saling ketergantungan (interdependence).Menurut hasil kajian para ilmuwan segala yang ada di dunia ini adalah saling berhubungan dan tergantung. Oleh karena itu transformasi budaya Aswaja jangan dilepaskan dari masalah-masalah yang muncul di pesantren lain dan masyarakat secara luas.

b. Diferensiasi (differtation) menunjukkan kreativitas yang luar biasa dari alam semesta yang memilik sifat perbedaan, keseragaman dan keunikan. Karena itu perbedaan, keseragaman dan keunikan masing-masing individu santriserta perbedaan dan keunikan masing-masing pesantren diharapkan dapat dijadikan pertimbangan dalam melaksanakan transformasi budaya di suatu pesantren.

c. Pengorganisasian diri (self organization) yaitu setiap individu atau kesatuan alam semesta mempunyai potensi yang melekat, yaitu kesadaran sebagai kesatuan utuh yang berbeda dari yang lain. Karena itu transformasi budaya di sebuah pesantren di sesuaikan dengan potensi, kekuatan dan kesempatan yang dimilikinya. Sebuah pesantren tidak bisa meniru sepenuhnya terhadap transformasi budaya Aswaja di pesantren lain, tanpa mempertimbangkan potensi dirinya.

Langkah-langkah diatas lebih menunjukkan bahwa proses transformasi budaya Aswaja di pesantren, secara garis besar dimulai dengan pembiasaan dan pencairan, pengubahan dan pemantapan, senada dengan teori proses perubahan Kurt Lewin yaitu 
unfreezing, changing dan refreezing ${ }^{42}$ dan teori perubahan menurut Abdullah Ulwan pembiasaan (ta'wid), penuntunan dan latihan (talqin) dan pendidikan dan pengajaran (ta'dib). ${ }^{43}$ Proses ini sedikit berbeda dengan tahapan dakwah menurut Hasan al Banna yaitu pengenalan (ta'rif), pembentukan (takwin) dan pelaksanaan (tanfid $)^{44}$

Agar transformasi budaya dapat dilakukan dengan sempurna maka perlu melakukan institusionalisasi Aswaja sebagai berikut:

a. Membentuk lembaga khusus kajian Aswaja

b. Mengadakan kaderisasi Ablussunnah Wal Jamäah

c. Pembiasaan nilai-nilai aswaja melalui kegiatan sehari-hari

d. Memasukkan kompetensi keAswajaan dalam rekrutmen guru dan tenaga kependidikan

e. Pembuatan rancangan kurikulum yang bermuatan aswaja.

f. Pembelajaran kitab di pesantren dan madrasah serta pembelajaran buku-buku aswaja dari LP Ma'arif di sekolah.

\section{Kesimpulan}

Menyimak realitas transformasi budaya Aswaja di pesantren maka dapat dipahami bahwan nilai-nilai budaya Aswaja yang diterapkan di pesantren meliputi: niali tawasut, tawazun, tasamuh dan adl. Pesantren lebih banyak melakukan pembiasaan dari pada internalisasi dan institusionalisasi budaya tersebut. Respon internal dan eksternal pesantren sebenarnya sudah baik terhadap transformasi budaya Aswaja yang dilakukan di pesantren sehingga jumlah santri di pesantren dengan segala tipologinya semakin bertambah dari tahun ketahun. Untuk lebih meningkatkan respon tersebut maka pesantren perlu memaksimalkan internalisasi dan institusionalisasi budaya Aswaja.

\section{Referensi}

Abdusshomad, Muhyiddin. Hujjah NU Akidah Amaliyah Tradisi. Surabaya: Khalista, 2008.

Abidin, Hasan Ahmad. Huquq al Insan wa wajibatibi fi al Qur'ah. Makkah: ats Tsaqafah, 1984.

Abu Faris, Muhammad Abdul Qadir. al Qadha' fi al Islam. Oman: al Aqsha, 1978.

Ad Ddimasyqi, Muhammad Jamaluddin al Qasimi Tt. Mau'idzah al Mu'minin. Beirut: Dar al fikr

Al Alma'I, Zahir bin 'Iwad. Dirasat fi at Tafsir al Maudlu'I li al Qur'an al Karim. Riyadh: al Farardaq at Tijariyah, 1983.

Al Qardawy, Yusuf. al Khashaish al 'Ammah li al Islam. Kairo: Muassasah ar Risalah, 1977.

Al Qardhawi, Yusuf. Al-Iman Wa Al- Hayah. Bairut: Muassasah Ar-risalah, 1998.

42 Stephen P.Robbins, Essentials Organizational Behavio (London: Prentice-Hall International, 1983),183.

${ }^{43}$ Abdullah Ulwan, Tarbiyah al Awlad fi al Islam, juz 2 (Beirut: Dar as Salam li at taba'ah wa an nasyr wa at Tauzi', tt), 65

44 An Nadwah al Alamiyyah li as Syabab al Islamy, Mausu'ah al Muyassarah fi al Adyani (Riyadh: WsAMY, 1972), 27 
An Nadwah al Alamiyyah li as Syabab al Islamy. Mausu'ab al Muyassarah fi al AdyaniRiyadh: WAMY, 1972,

At Turk, Abdullah bin Muhsin. Majmal I'tiqad Aimmah As Salaf. Beirut: Asy Syarikah al Muttahidah li at Tawzi', 1992..

Barlette, Steve, dan Diana Burton. Introduction to Education Studies, Edisi 2.Los Angles: SAGE Publication, 2007.

Depertemen Republik Indonesia Direkterot Jenderal Pendidikan Islam, Direktorat Pendidikan Islam, Post-Tradisionalisme Islam. Jakarta: DEPAK. 2007

Forum kajian ke-NU-an. Khittah dan Khidmah. Pati: Raudlah at-Tahiriyah, 2014.

Gary R. Morrison. Designing Effective Instruction. Hoboken: River Street, 2011.

Gunawan, Ali Hasan Siswanto. Islam Nusantara dan Kepesantrenan. Yogyakarta: Interpena, 2016.

Halim, Asep Syaifuddin. Membumikan Aswaja Pegangan Para Guru NU. Surabaya: Khalista, 2015.

Hordin, Carlette Jackson. Effective Classroom Management. New Jersey: Upper Saddle River, 2004.

O’Nell, William F. Educational Ideologies Contemporary Expressions of Education Philosophies. California: Good Year Publishing Compani, 1981.

Powell, Angela. Classroom Management That Makes Teaching More Effective, Efficient and Enjoyble. USA, 2009.

Pranata, David. Communication Made Easy. Jakarta: Media Komputindo, 2016.

Qutub, Sayyid. Fi Drilal al Qur'an, jilid 2. Beirut: Dar asy Syuruq, 1972.

Robbins, Stephen P. Essentials Organizational Behavio. London: Prentice-Hall International, 1983.

Schein, Edgah H. Organizational Culture dan Leadership. San Francisco: Jossey-Bass, 2010.

Sutriono, Edy. Budaya Organsasi. Jakarta: Kencana, 2010.

Tim Aswaja Center. KhazanahAswaja. Surabaya:Aswaja NU Center, 2016.

Tim Penulis Batartama. Trilogi Ablus sunnah, Akidah, Syariah dan Tasawnf. Pasuruan: Pustaka Sidogiri, 2015.

Ulwan, Abdullah Nasih. Tarbiyah al Awlad fi al Islam, jur. 2. Beirut:Dar as Salam, 1979.

Waruwu, Fidelis E. Membangun Budaya Berbasis Nilai. Yogyakarta: Kanisius, 2010.

Yamin, Mohammad.Vivi Aulia. Meretas Pendidikan Toleransi. Malang: Madani, 2011.

Yukl, Gary. Kepemimpinan dalam Organisasi ( ed. 5), terj Budi Supriyanto. New Jersey: Prentice - Hall Inc, 2005.

Zamroni. Pengantar Pengembangan Teori Sosial. Yogyakarta: Tiara Wacana Yogya, 1992. 